\section{Furuncular Myiasis Affecting the Lower Lip of a Young Patient}

Felipe Paiva Fonseca, José Ribamar Sabino-Bezerra Jr., Pablo Agustin Vargas,

Oslei Paes de Almeida, Marcio Ajudarte Lopes, Alan Roger Santos-Silva
Department of Oral Diagnosis

(Semiology and Pathology)

- Piracicaba Dental School -

UNICAMP - Universidade de

Campinas, Piracicaba, SP, Brazil

Correspondence: Alan Roger Santos Silva, Avenida Limeira, 901, Bairro Areão, 13414-903 Piracicaba, SP, Brasil. Tel: +55-19-2106-5200. e-mail: alanroger@fop.unicamp.br

Key Words: myiasis, furuncular myiasis, dermatobia

hominis, oral cavity, lip.

\section{Introduction}

Myiasis is the infestation of tissues or organs of animals and humans caused by the larvae of Dipteran flies, whose eggs are commonly deposited in wounds, ulcers or intact skin. This parasitosis is classified based on the infested tissue/organ, which includes cutaneous, oral, aural, nasopharyngeal, ocular, intestinal/enteric, rectal and urogenital types (1-4). The cutaneous form is the most common and it is further sub-classified according to the clinical features and type of larvae as furuncular, migratory and wound myiasis $(2,3,5)$.

Furuncular myiasis is more common in tropical countries; however, along with globalization there is an increasing number of cases diagnosed in travelers returning from endemics areas $(3,6,7)$. In sub-Saharan Africa furuncular myiasis is caused by the tumbu fly Cordylobia anthropophaga, whereas the human botfly Dermatobia hominis is commonly found in Mexico and all of Latin America (8-10).

The oral cavity is not a frequent location to be affected and most cases of oral myiasis described in literature have been reported from Brazil, India and Turkey. The anterior maxillary and mandibular gingiva represent the most common sites, most likely due to accessibility of flies and different local, systemic and environmental factors, which predispose to oral infestation, including poor oral hygiene, periodontal diseases, suppurating lesions, mouth breathing, anterior open bite, lip incompetence, trauma, mental impairment, cerebral palsy, epilepsy, neurological deficits, alcoholism, poor food hygiene, low socioeconomic status, humid warm weather and travel to endemic areas $(11,12)$.

On the other hand, very few cases of furuncular myiasis caused by Dermatobia hominis in the oral and perioral regions are currently available in English language literature
$(13,14)$. Recognizing this condition in this uncommon anatomic location is very important to appropriately distinguish it from other more common differential diagnoses. Therefore, the objective of this paper is to describe a rare case of furuncular myiasis affecting the lower lip of a young healthy man.

\section{Case Report}

A 20-year-old male patient first presented to his general medical practitioner with a weeklong persistent lower lip swelling, which was treated with systemic antibiotics for 3 weeks. The swelling persisted and the patient was referred to this department.

Clinical examination revealed a soft, well-circumscribed swelling on the lower lip measuring $3 \mathrm{~cm} \times 3 \mathrm{~cm}$ (Figs. 1A and $1 \mathrm{~B}$ ). The overlying skin was erythematous and painful, showing a firm furuncular-like lesion with a central pore that drained serous discharge (Figs. 1C and 1D). The patient reported itching and movement sensation in the affected site and a careful clinical observation revealed the intermittent presence and absence of a non-specified yellowish structure in the cutaneous pore. According to the patient, there was no trauma or other relevant local factors associated and medical history was not contributory.

The differential diagnosis included folliculitis and infected epidermoid cyst. After a superficial incision under local anesthesia, surgical exploration of the nodule was performed and a live maggot emerged from the lesion immediately after the initial incision. The wound was irrigated thoroughly with saline solution and closed with sutures.

The maggot was submitted to histopathological analysis. On gross examination, the larvae appeared as a cylindrical, 
yellow to brownish maggot with evident hooks in the cephalic portion and rows of cuticular spines surrounding its body. At the caudal end, posterior spiracles were observed (Fig. 2). Microscopically the larvae exhibited thick acellular body walls with cuticle spines, with prominent internal striated muscles and posterior spiracles (Fig. 3), consistent with the species Dermatobia hominis. Considering the clinical features and the larvae, the final diagnosis was of furuncular myiasis. The exploratory surgery was both diagnostic and curative. Successful healing was observed in the following appointment. After 3 years of follow-up, the patient is recovered, with no clinical signs or symptoms of the disease (Fig. 4).
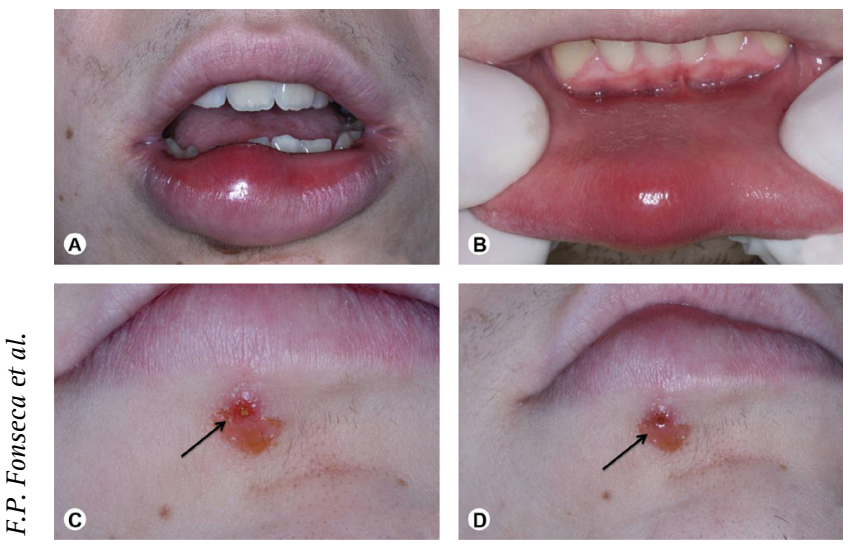

Figure 1. A and B: Swelling affecting the lower lip of a young male. C: Extra-oral aspect depicting a furuncular-like skin lesion with central pore. During clinical evaluation, was observed an intermittent presence and absence of the caudal respiratory spiracle of the larvae in the cutaneous pore. This image illustrates the moment when larva spiracle can be observed (arrow). D: In this image, in addition to the serosanguineous fluid draining from the furuncular-like lesion, it is possible to observe that the spiracle is no longer present in the central pore (arrow).
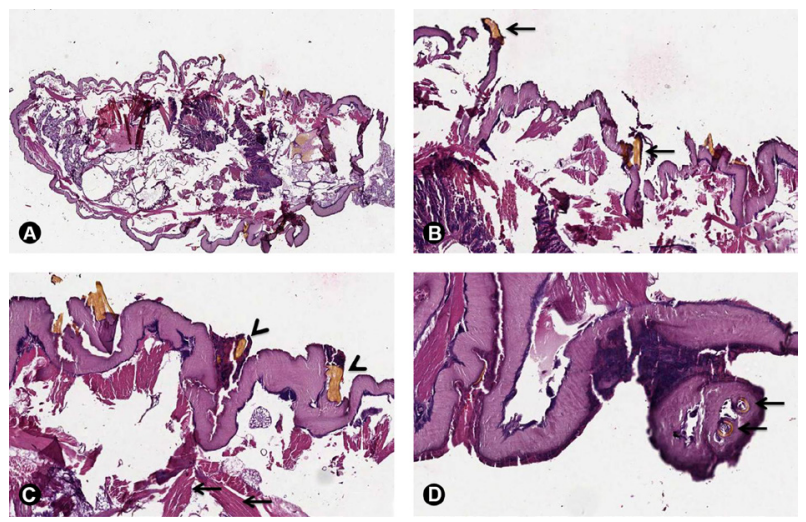

Figure 3. A. Overview of the microscopic features of the larvae (H.E., 10x). B. Thick cuticle spines limiting the larva body (arrows) (H.E., 20x). C. External cuticle spines as part of the body wall (arrowhead) (H.E., 40x). D. Posterior spiracles of the larva (H.E., 100x).

\section{Discussion}

The term myiasis was coined in 1840 by the reverend Frederick William Hope, but this condition had been known since ancient times $(15,16)$. Myiasis is a type of parasitosis which involves the infestation of body tissues of humans and animals by dipteran larvae which feed on host's necrotic or living tissue, liquid body substances or ingested food $(4,15,17)$. In a recent literature review, Singh et al. (4) described approximately 37 different fly species belonging to ten families as responsible worldwide for the onset of human myiasis and the most frequently reported were those from the family Calliphoridae, Sarcophagidae, Oestridae, Muscidae, Psychodidae, Syrphidae, Phoridae, Drosophilidae, Dryomyzidae and Gasterophilidae. Regarding oral myiasis, species that have already been reported include Cochliomyia hominivorax, Oestrus ovis, Wohlfahrtia magnifica, Chrysomya bezziana, Hypoderma

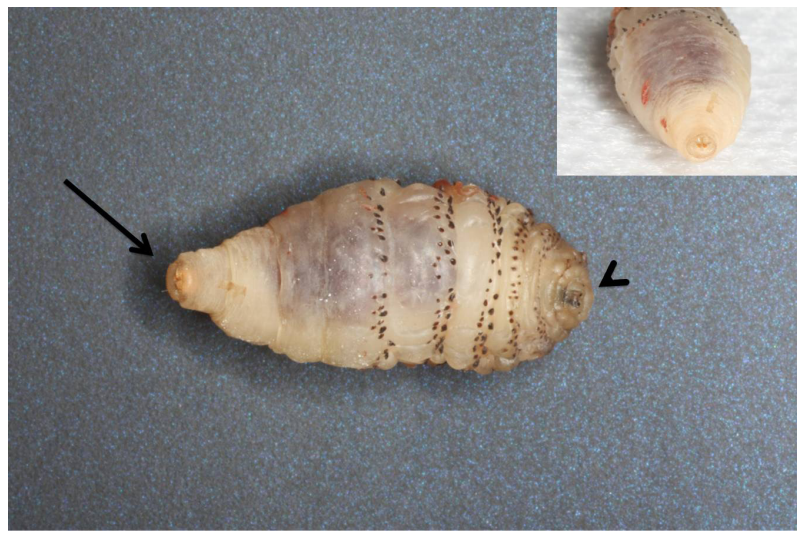

Figure 2. Ventral view of the barrel-shaped, yellowish larvae showing the cephalic portion of the larva with ventral hooks (arrowhead), several rows of cuticular spines surrounding its body and the posterior spiracles at the caudal end (arrow). The insert at the right superior corner provides a closer view of the spiracles that were observed, as shown on Figure 1C.

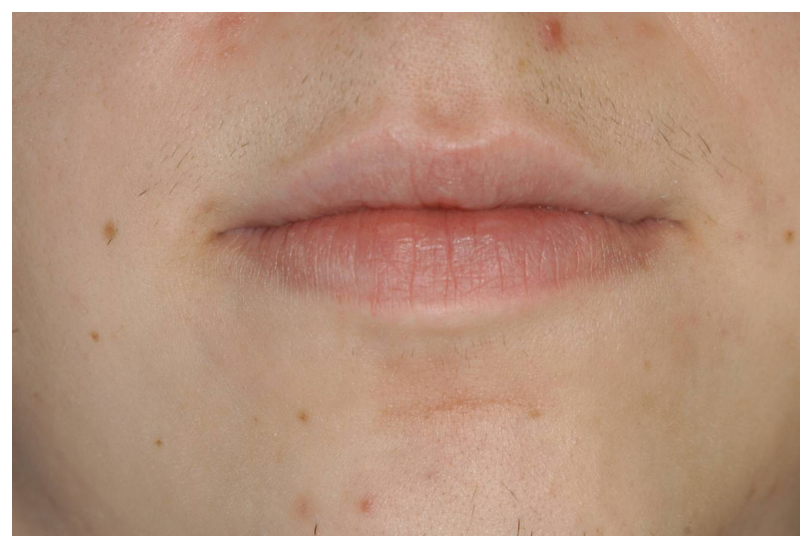

Figure 4. Three years after removal of the larva, the lip was normal, without signs or symptoms. 
bovis, Dermatobia hominis, Cordylobia anthropophaga, Hypoderma tarandi, Calliphora vicina, Musca nebulo, Musca domesticus and Lucilia sericata (11).

Myiasis can be classified as obligatory, facultative and accidental when larvae develop in living tissue, when maggots feed on necrotic tissue and when larvae are ingested along with food, respectively $(16,18)$. Another scheme classifies myiasis as either primary, more commonly seen in cattle, caused by larvae that feed on living tissue. It is produced by Cochliomyia hominivorax that lays hundreds of eggs on exposed wounds, with larvae hatching within $24 \mathrm{~h}$ or secondary, which represents the most common type in humans and is caused by flies that feed on dead tissue in patients with necrotic lesions $(19,20)$. However, its classic classification is based on the infested tissue/ organ and includes cutaneous, oral, aural, nasopharyngeal, ocular, intestinal/enteric, rectal and urogenital types $(3,4)$. The cutaneous form is the most common and it is further sub-classified according to the clinical features and types of larvae as furuncular, migratory and wound myiasis $(2,3)$.

Wound myiasis is the most common in the oral and perioral region. It is rare in healthy persons, and usually secondary to medical conditions such as cancrum oris, neglected mandibular fracture, cerebral palsy, mouth breathing, anterior open bite, incompetent lips, and patients undergoing mechanical ventilation (21). Migratory myiasis is caused by the larvae of horse and cattle bot flies. It is not commonly found in humans because larvae cannot develop further, but they produce tunnels in the epidermis allowing their migration over long distances (3). On the other hand, furuncular myiasis may affect intact skin of healthy patients, causing a small, raised, reddish, bite-like lesion that evolves into an enlarging, pruritic, erythematous, tender nodule, associated with a sensation of movement and intermittent pain (10).

Furuncular myiasis is widely described in both the dermatologic and infectious disease literature; however, very few cases previously described in English language literature of furuncular myiasis were found affecting the perioral region, involving mostly the upper lip, with no reports found for the lower lip $(13,14)$.

Furuncular myiasis is caused by various species of flies, usually distinguished by their different life cycles. Dermatobia hominis is the most common in Latin America; while Cordylobia anthropophaga is found in Africa, Cuterebra myiasis and Wohlfahrtia vigil in North America, and Hypoderma lineatum in Nepal $(3,9)$. However, in recent decades, due to increasing travels to endemic areas and mass migration, cases of furuncular myiasis may be diagnosed everywhere in the world (10).

Flies can transmit their larvae to humans in different ways. Some of them attach their eggs to mosquitoes that transmit the larvae via their bites. Other flies' larvae (known as screwworms) can enter skin through bare feet or attach themselves to clothes and then burrow into the skin of the human; and some flies deposit their larvae in, on, or near a wound (11). It is suggested that the botfly Dematobia hominis does not lay the eggs directly on the host. Instead, the female botfly attaches eggs firmly to the abdomen of a day-active mosquito. When the latter visits an animal or human host, the increase in temperature helps to hatch the eggs allowing the larvae to enter the skin through the insect bite or following a hair follicle $(2,3,5)$. This was the probable mechanism of the present case.

One day after the larval deposition, a small slightly reddened papule appears, and a few weeks later it expands into a dome-shaped itching and tingling nodule $(8,9,13)$. An important clinical sign of furuncular myiasis is a serosanguineous or seropurulent drainage from the central pore of the nodule, containing the caudal respiratory spiracle of the larvae $(2,3,13)$. This clinical parameter was present in the current case and is useful to distinguish furuncular myiasis from other entities that present a yellowish secretion like epidermal cyst (keratin component) and infected hair follicle (purulent secretion). In addition, the intermittent presence and absence of the caudal respiratory spiracle of the larvae in the cutaneous pore, as occurred in the present case, may also be used as an additional fact to reach a proper diagnosis.

Other diagnostic possibilities initially considered for the current case included mucous extravasation phenomenon, excluded because the extensive involvement of the cutaneous portion of the lip is usually not expected for mucoceles. Also, pain is not a frequent associated symptom, no traumatic episode was described and the serous drainage was not consistent with this common salivary gland lesion. Benign mesenchymal neoplasias, like schwannoma, neurofibroma, angioleiomyoma, fibrous histiocytoma and solitary fibrous tumor were excluded because of the painful symptomatology of the patient together with the abrupt initial growth followed by maintenance of size, with serous discharge. Additionally, a granulomatous inflammatory adverse reaction against foreign bodies especially synthetic fillers used for cosmetic facial surgery was excluded due the absence of cosmetic surgery and previous traumas history.

Treatment of furuncular myiasis tends to be simple, with occlusion of the central pore of the soft tissue lesion, causing anoxia of the infesting larvae $(2,3,5,8,9)$, followed by surgical debridement under local anesthesia $(5,9,10,15,18)$. However, some care must be taken since when fragments of the larva remain on the site, hypersensitivity and/or a foreign-body reaction response may occur, or infection may spread to other regions $(9,15)$. Also, topical $10 \%$ ivermectin for $2 \mathrm{~h}$ could be used to kill the parasite $(8,12,19)$. Systemic 
ivermectin is rarely required in patients with widespread lesions. In this report, a superficial exploratory surgery that removed the only maggot present in the lower lip, followed by appropriate irrigation and cleaning of the surrounding tissues, proved to be curative and the patients is free of lesion after 3 years of follow-up.

Recommendations for histological processing of the findings include killing the larvae by immersion in hot but not boiling water $\left(80^{\circ} \mathrm{C}\right)$ for $30 \mathrm{~s}$, followed by fixation in $70 \%$ to $95 \%$ ethanol. As illustrated in the current report, formalin solutions should be avoided because they cause excessive hardening of tissues, making difficult the histological processing and damaging the tissue (2). The microscopic features observed in this case included a thick acellular body walls with cuticle spines, prominent internal striated muscles and posterior spiracles, together with a macroscopic aspect of the larvae with a cylindrical, yellow to brownish format and circular arrangement of spines that provide larval attachment to adjacent host tissue, were consistent with Dermatobia hominis species (22).

In summary, the present report illustrates an unusual case of furuncular myiasis involving the lower lip that was diagnosed transurgically. Furuncular myiasis is frequently $\vec{s}$ misdiagnosed as bacterial abscess or infected epidermoid cyst and mistakenly treated with systemic antibiotics, as happened initially in the present case. Finally, this diagnosis should be considered not only in tropical countries as in Africa and Latin America, but worldwide due to increasing globalization and migration.

\section{Resumo}

A miíase furuncular é uma infecção parasitária causada pelas larvas de insetos Dipterans após penetrar na pele saudável, causando um nódulo eritematoso contendo um poro central. Adicionalmente, uma sensação de movimento e dor intermitente pode ser sentida. Miíase furuncular acometendo a região oral e perioral é rara, frequentemente causando erros diagnósticos. Este artigo descreve um caso raro de miiase furuncular em um paciente do sexo masculino de 20 anos de idade que apresentou um nódulo eritematoso no lábio inferior. Uma cirurgia exploratória foi indicada para fins diagnósticos e curativos, com sucesso observado já na sessão seguinte. Após 3 anos de acompanhamento, o paciente está recuperado, sem sinais clínicos ou sintomas da doença.

\section{References}

1. Millikan LE. Myiasis. Clin Dermatol 1999;17:191-195.

2. McGraw TA, Turiansky GW. Cutaneous myiasis. J Am Acad Dermatol 2008;58:907-926.

3. Robbins K, Khachemoune A. Cutaneous myiasis: a review of the common types of myiasis. Int J Dermatol 2010;49:1092-1098.

4. Singh A, Singh Z. Incidence of myiasis among humans - a review. Parasitol Res 2015;114:3183-3199.

5. Maier $\mathrm{H}$, Honigsmann $\mathrm{H}$. Furuncular myiasis caused by Dermatobia hominis, the human botfly. J Am Acad Dermatol 2004;50:S26-S30.

6. Droma EB, Wilamowski A, Schnur H, Yarom N, Scheuer E, Schwartz E. Oral myiasis: a case report and literature review. Oral Surg Oral Med Oral Pathol Oral Radiol Endod 2007;103:92-96.

7. Clyti E, Deligny C, Nacher M. An urban epidemic of human myiasis caused by Dermatobia hominis in French Guiana. Am J Trop Med Hyg 2008;79:797-798.

8. Lane JE, Rogers RM, Mullins S, Lesher JL Jr. Furuncular myiasis secondary to Dermatobia hominis. J Drugs Dermatol 2005;4:365-368.

9. Jelinek T, Nothdurft HD, Rieder N, Loscher T. Cutaneous myiasis: review of 13 cases in travelers returning from tropical countries. Int J Dermatol 1995 34:624-626.

10. Boggild AK, Keystone JS, Kain KC. Furuncular myiasis: a simple and rapid method for extraction of intact Dermatobia hominis larvae. Clin Infect Dis 2002;35:336-338.

11. Hassona $Y$, Scully $C$, Aguida M, Almeida OP. Flies and the mouth. J Invest Clin Dent 2014;5:98-103.

12. Saravanan $T$, Mohan $M A$, Thinakaran $M$, Ahammed S. Oral myiasis. Indian J Palliat Care 2015;21:92-94.

13. Messahel A, Sen P, Wilson A, Patel M. An unusual case of myiasis. J Infect Public Health 2010;3:43-45.

14. Freitas DA, Moreira G, Jones KM, Caldeira AP. Social exclusion and myiasis of the upper lip in a Brazilian rural resident. Rural Remote Health 2012;12:2188.

15. Corrêa APS, Beneti IM, Ribeiro ED, Pereira CCS, Souza FA, Garcia-Júnior IR. Myiasis in elderly involving oral and nasal cavities - diagnosis and treatment. J Craniofac Surg 2015;26:989-990.

16. Sharma D, Kumar $S$, Parashar $P$, Naphade W. Oral gingival myiasis: $A$ rare case report and literature review. Contemp Clin Dent 2015区6:548551.

17. Ogbalu OK, Achufusi TGO, Orlu EE. Epidemiology of human furuncular myiasis of Cordylobia anthropophaga (Grunberg) in Nigeria. Int J Dermatol 2013;52:331-336.

18. Kumar $P$, Singh V. Oral myiasis: case report and review of literature. Oral Maxillofac Surg 2014;18:25-29.

19. Shinohara EH, Martini MZ, Oliveira-Neto HG, Takahashi A. Oral myiasis treated with Ivermectin: Case report. Braz Dent J 2004;15:79-81.

20. Antunes AA, Santos TS, Avelar RL, Martins-Neto EC, Neres BM, Laureano-Filho JR. Oral and maxillofacial myiasis: a case series and literature review. Oral Surg Oral Med Oral Pathol Oral Radiol Endod 2011;112:e81-e85.

21. Ribeiro AL, de Almeida TE, Lopes JS, Jr., Castro JF, Pinheiro J de J. Oral myiasis: does an indication for surgical treatment still exist? Two case reports. Oral Surg Oral Med Oral Pathol Oral Radiol 2012;114:e10-e4.

22. Möhrensclager $M$, Mempel $M$, Weichenmeier I, Engst $R$, Ring $R$, Behrendt $H$. Scanning electron microscopy of Dermatobia hominis reveals cutaneous anchoring features. J Am Acad Dermatol 2007;57:716-718.
Received February 17, 2016 Accepted July 5, 2016 